\title{
11. THE BEDROCKS FROM THE BLACK SEA BOTTOM AND SOME FEATURES OF THE DEEP-SEA BASIN STRUCTURE
}

\author{
K. M. Shimkus, Ya. P. Malovitskỵ, Southern Branch, P. P. Shirshov Institute of Oceanology, Gelendgik 7, Krasnodar Region, \\ USSR \\ and \\ S. I. Shumenko, Kharkov University, USSR
}

\section{INTRODUCTION}

Many recent geophysical investigations of the Black Sea Basin have enabled the basic tectonic features and geological development of this large midland basin to be outlined. Nevertheless, knowledge of the submarine rock outcrops is meager and it was toward enlarging this information that, under the initiative of Ya. P. Malovitsky, the Southern Division of P. P. Shirshov Institute of Oceanology, USSR Academy of Sciences, systematic study of the bottom rocks on the continental slope was investigated.

From 1973 to 1975 , expeditions of the R/V Academician $S$. Vavilov, under guidance of the senior author, dredged the Caucasian, Turkish, and Crimean slopes from which numerous bedrock samples were obtained, including samples from the steepest parts of the slopes (Figure 1). The upper part $(100-500 \mathrm{~m})$ of the Caucasian slope, the upper and middle parts of the Crimean slope, and the lower part of the Turkish slope are the best exposed. $\mathrm{CaCO}_{3}$ and $\mathrm{SiO}_{2}$ amorph. were determined for most of the samples, and the petrology of the rocks also was studied. Age determinations, based on foraminifers, were done by T. A. Malakhova and D. A. Strocheva in the stratigraphy laboratory of KrasnodarNIIneft. Study of nannoplankton in some samples was done by S. I. Shumenko. The results of these investigations are partially published (Shimkus and Shumenko, 1975).

\section{GELENDGIK-NOVOROSSIISK SLOPE}

In this area bedrock samples were collected at 10 stations, mainly from the upper part of the slope (depth from 230 to $630 \mathrm{~m}$ ). At two stations, 2007 and 2008, dredging was done at depths from 250 to 1000 meters (Figure 1A).

The continental slope here consists of benches partially covered by young deposits (Figure 2) composed of dark gray and blackshydrotroilitic clay containing late Pleistocene Dreissensia and rock fragments. Some dredges of Recent terrigenous muds contained rounded fragments of plastic clays.

The slope comprises terrigenous flysch of Paleocene and Eocene age as determined by foraminifers. The Paleocene rocks consist mainly of argillites, argillite-like clays with lesser silts, sandstones, marls, and limestones, which assemblage is rather similar to Paleocene sediments cropping out on the the Black Sea coast near Anapa; there, sandstones are more widespread. The Eocene deposits are mostly green clays, with subordinate sandstones, similar to a green unit of early Eocene age in the northwestern Caucasus. Conglomerates, probably of late Paleogene or Neogene age also occur.
In addition to Paleocene and Eocene foraminifer faunas contained in these rocks, reworked Maestrichtian forms are common.

In seismic profiles crossing this area, two singular structural units are apparent (Figure 3A) in the upper slope. The lower unit consists of strongly dislocated Upper Cretaceous-Eocene rocks overlain by a unit (Majkop and younger) which is here distorted (Terekhov et al., 1970, 1973; Malovitsky and Terekhov, 1972). Our observations confirm the latter but show that, in the upper part of the slope, Majkop deposits are missing. It appears that, in this area, uplift took place toward the close of Eocene time, coinciding with the rise of the northern slopes of the Novorossiisk and Lazarevsky flysch troughs. The Semigorskae uplift became exposed (Shardanov, 1960; Djakonov et al., 1972) and Majkop rocks were removed, their remains being deposited at the foot of the continental slope.

\section{SUBMARINE ARKHANGELSKY RIDGE}

This elongate bottom topographic feature stretches northwestward from the Turkish coast (Figure 1B). The ridge slopes have low gradients and are mostly covered with unconsolidated sediments but uncovered upper Pleistocene viscous clays crop out in places. Dredging in three areas (Figure $4 \mathrm{~A})$ was done in water depths of 630-1500 meters.

Near the crest (Stations 2261, 2264) Cretaceous pyroclastics, sandy argillites, and carbonates occur, an assemblage similar to and widespread along the neighboring coast (Figure 1B) (Erentoz, 1967; Brinkmann, 1974).

The steepest low part of the northeastern ridge slope (Station 2261, 1000-1500 m) comprises green-gray, altered volcanic lithic crystal and vitroclastic andesite tuffs poorly cemented with montmorillinite (Figure 5D). Numerous fragments of semi-altered andesitic volcanic glass and andesites with hyalopilitic structures occur therein. Weathered plagioclase, chloritized biotite and quartz grains are present

(Figure $6 \mathrm{a}, \mathrm{b}$ ). The tuffs are in contact with light gray, breccia-like limestones or marls containing greenish tuffaceous clay inclusions and plagioclase crystals.

At Station $2264(830-1450 \mathrm{~m})$ the following Early Cretaceous foraminifers were recognized: Gyroidinoides infracretaceous (Morozova), Hedbergella infracretacea (Glaessner), H. planispira (Tapp), Glomospira gordialis (Jones and Parker), Gaudryina spessa (Berthelia), Clavulinoides gaultinus (Morozova), and Eponides chalilovi (Djaffarovi and Agalar).

The limestones are light gray to white, occasionally greenish gray and mottled. They may be fractured, with silica 


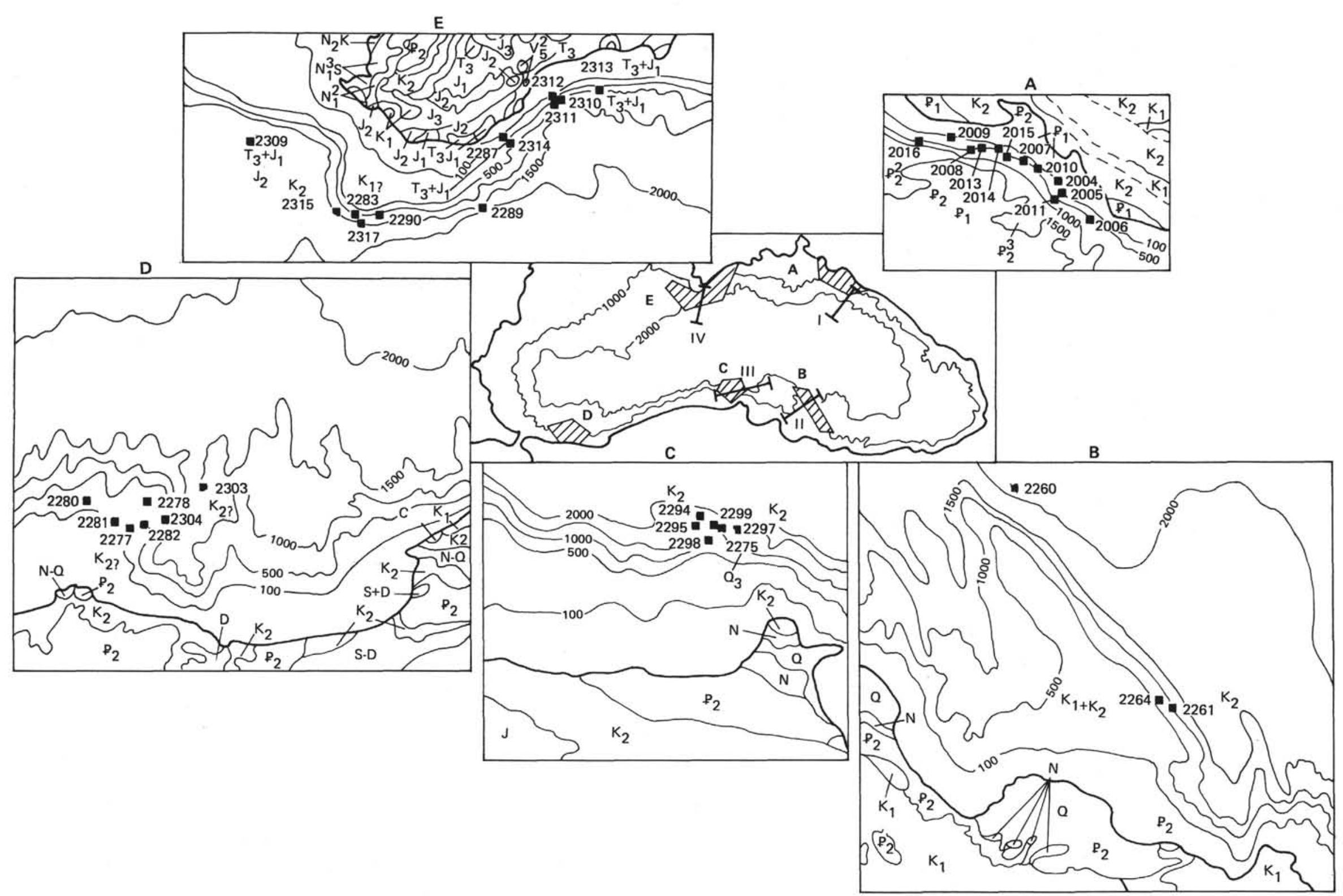

Figure 1. Locations of the dredging stations. Lines show the locations of the seismic profiles quoted. Shaded partsare areas of dredging: (A) Gelendgik-Novorossiisk region; $(B)$ submarine Arkhangelsky's Ridge; $(C)$ Sinopian area; $(D)$ submarine valley Sakarya; $(E)$ the Crimean region. 


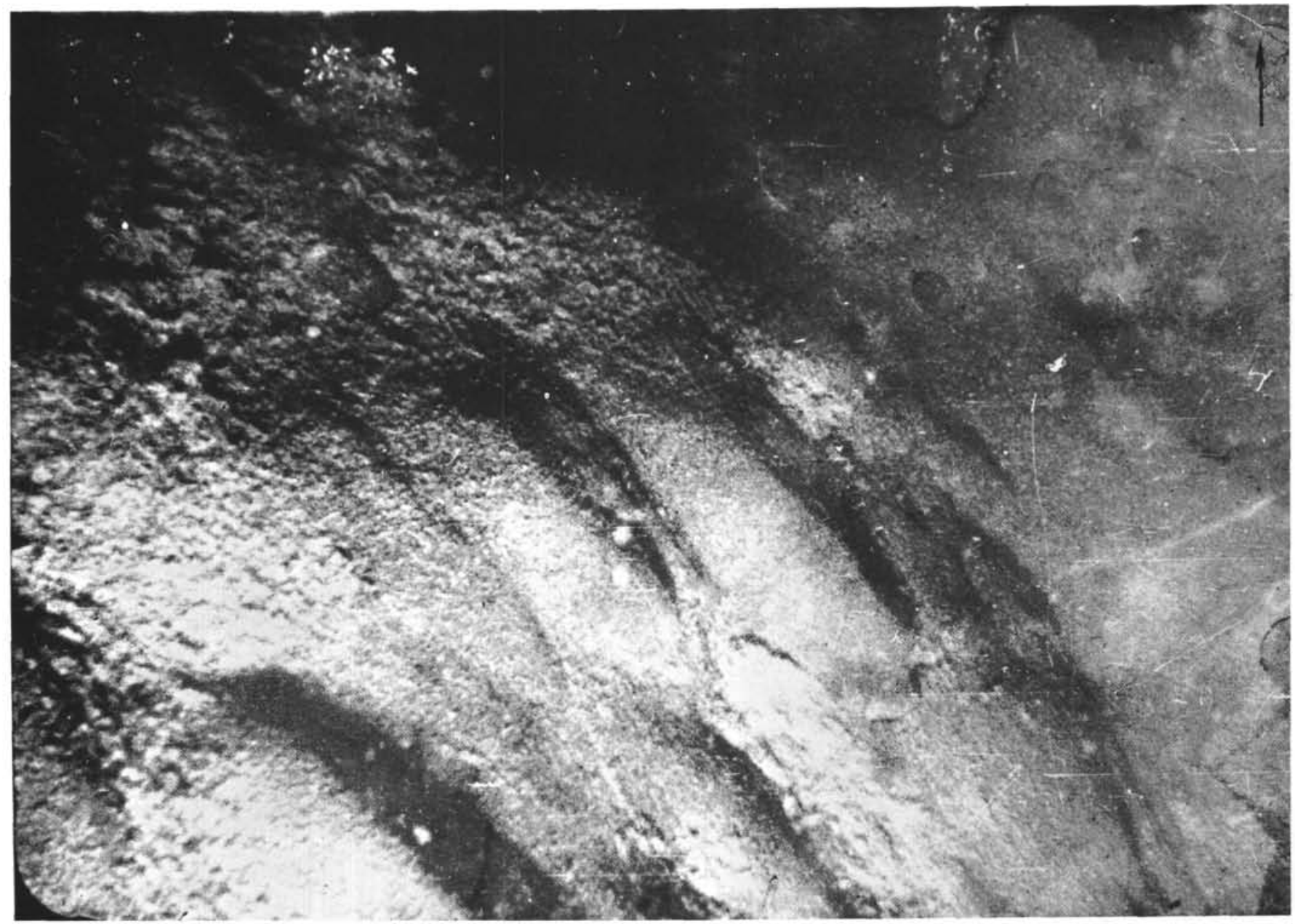

Figure 2. Outcrop of Paleogene flysch on the Black Sea continental slope opposite to Gelendgik (depth $650 \mathrm{~m})$ (submarine photograph taken by K. M. Shimkus using stereophotographic unit by N. L. Zenkevich).

filling the fractures. Also, at Station 2264, are limestone breccia/conglomerates, calcareous, green gray, finegrained, poorly cemented sandstones, and light gray calcareous aleurolites.

The clay section is best shown at Station 2261 where light gray clays, stained brownish yellow, and greenish gray noncalcareous, siliceous clays occur. They contain Santonian and reworked Cenomanian foraminifers such as: Globotruncana lapparenti (Br.), G. linneiana (Orb.), G. fornicata (Plamm), G. coronata (Bolli), Hedbergella planispira (Tapp.), H. infracretacea (Glaessner), Schackoina aff. multispinata (Cushman and Wickenden), $S$. aff. cenomana (Schacko), Gumbelina aff. striata (Ehr.), G. ex. gr. globulosa (Ehr.), Planoglobulinav sp. (aff. P. transcaucasica Alijulla), Parrella whitei (Brotz.), and P. crassa (Vass).

As confirmed by the incompleteness of the Cretaceous section-paleontologic and seismic data (Figure 3B and Malovitsky and Terekhov, 1973)_-Arkhangelsky's Ridge has experienced uplift and downdrop during Cretaceous and probably late Cretaceous time. These movements were of exceptional amplitude on its northeastern slope.

\section{THE SINOPIAN AREA}

Dredging results at Stations 2294, 2295, and 2299 (Figures 1C, 4B) show that steeper parts in the lower slopes expose outcrops of andesitic tuffs of aleuritic and aleuropelitic texture, and tuff breccias cemented with calcite; some contain shell debris and rare Late Cretaceous coccoliths. Limestones are abundant (Figure 5F) and consist of light gray clayey types, some of which are soft, chalk-like and contain abundant Late Cretaceous coccoliths such as: Watznaueria barneseae (Black), Cribrosphaerella ehrenbergi (Arkhangelsky), Zygodiscus diplogrammus (Deflandre), Prediscosphaera cretacea (Arkhangelsky), and $P$. propin$q u a$ (Gorka). Other light gray limestones, moderately indurated, contain rare Late Cretaceous Arkhangelskiella specimens.

In the lower slopes of the Sinopian area, semiconsolidated, light gray to green-gray nannoplankton oozes occur. They bear foraminifers and greenish clay balls. Higher, in the middle slope, similar sediments were dredged at Station 2275 (1400-1630 m); these nannoplankton oozes are enriched in organic matter (up to $11 \%$ Corg.), are consoli- 


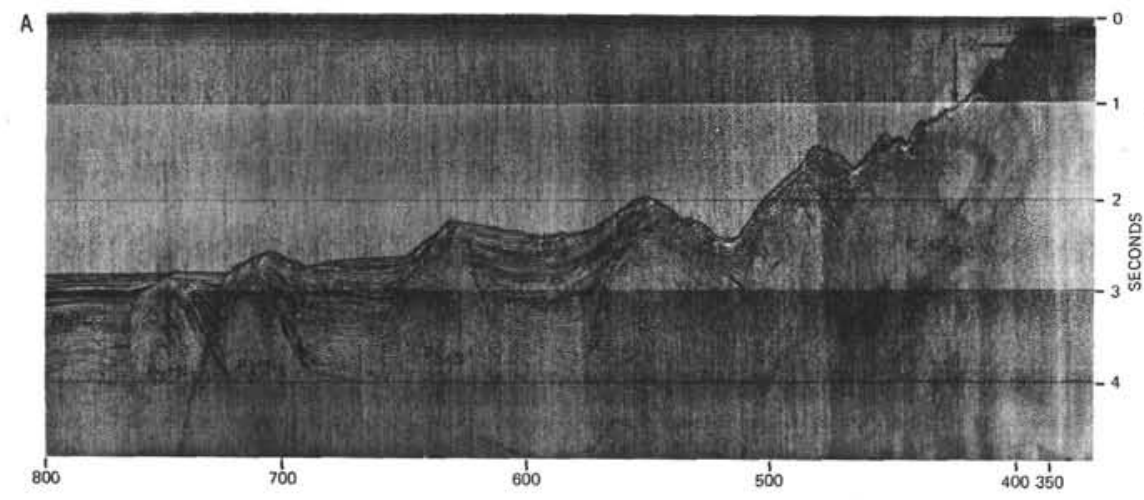

700

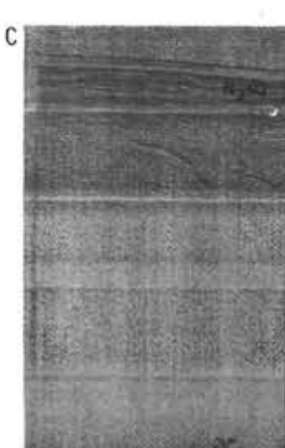

2400

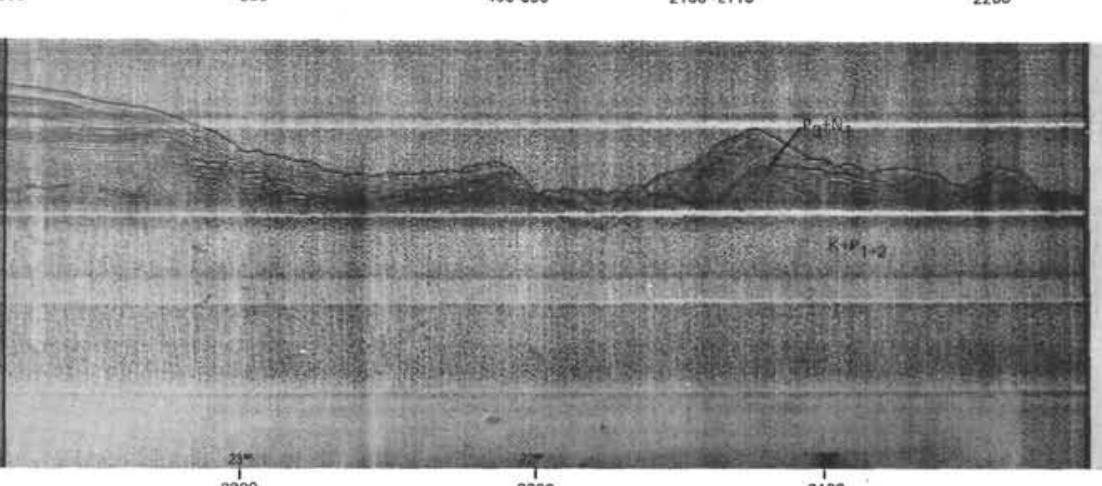

2300

2100
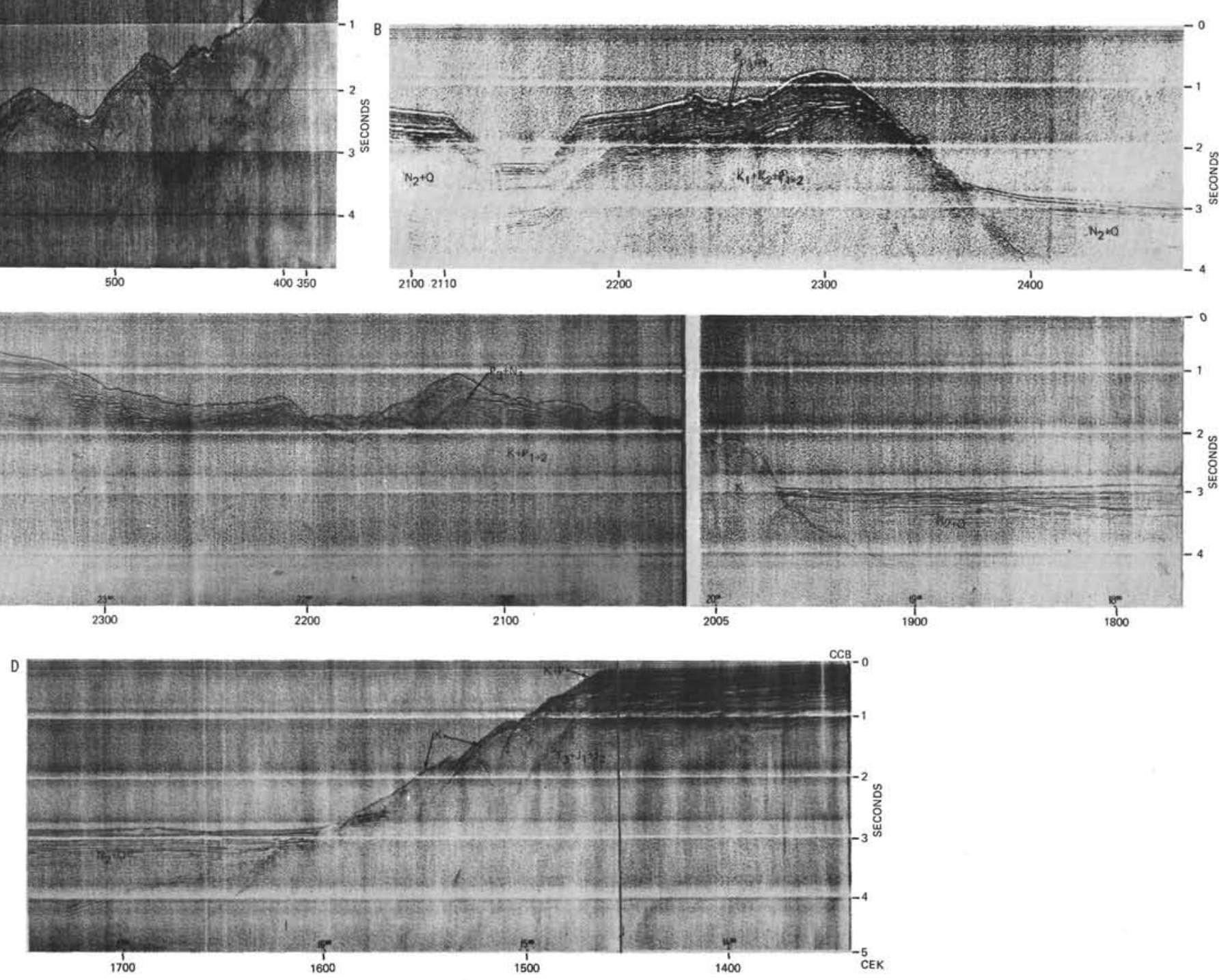

Figure 3. Profiles of continuous seismic profile shooting obtained by A. A. Terekhov (geological interpretation by Ya. P. Malovitsky, A. A. Terekhov, K. M. Shimkus). (A) Profile I (Caucasian slope). (B) Profile II (submarine Arkhangelsky's Ridge). (C) Profile III (Sinopian slope). (D) Profile IV (Crimean slope). 

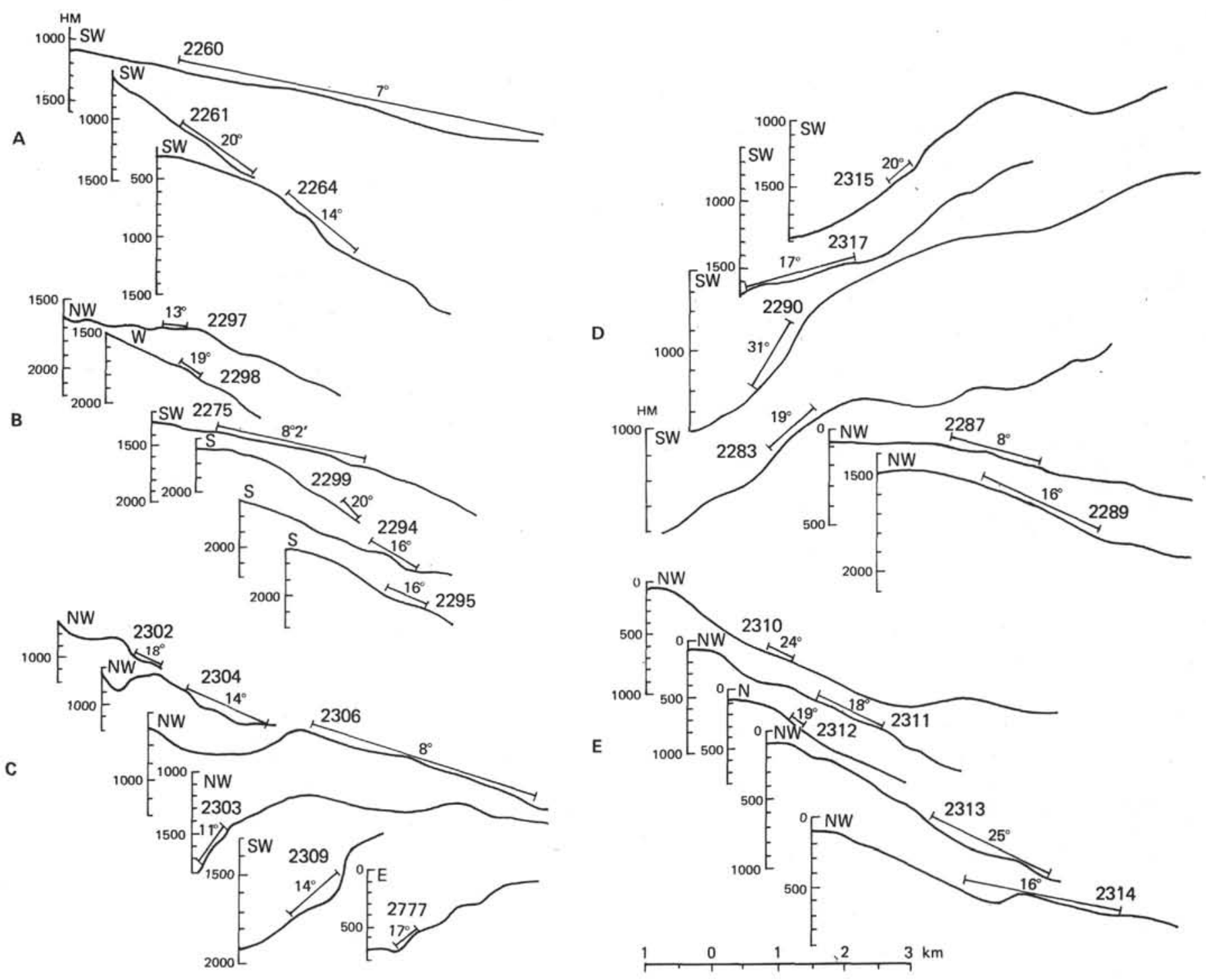

Figure 4. Bottom profiles with the areas of dredging: (A) submarine Arkhangelsky's Ridge; (B) Sinopian area; (C) submarine valley Sakarya, and Southwest Crimean area (Station 2309); (D) the Crimean slope (south area); (E) the Crimean slope (southeast area).

dated and finely laminated (Figures 5A, 6B, C). They are accompanied by finely laminated, low-calcareous to noncalcareous muds and clays, finely laminated to brecciated.

The nannofossil assemblage therein ranges in age from early Eocene to Pleistocene, with Paleogene species being abundant and well preserved (Figures 7a-d). The following forms have been identified: Discoaster barbadiensis (Tan Sin Hok), D. distinctus (Martini), D. lodoensis (Bramlette and Sullivan), $C D$. saipanensis (Bramlette and Riedel), $D$. sublodoensis (Bramlette and Sullivan), D. taninodifer (Bramlette and Riedel), Chiasmolithus gigas (Bramlette and Sullivan), C. titus (Gartner), Coccolithus eopelagicus (Bramlette and Riedel), C. formosus (Kamptner), C. tenuiforatus, etc. Neogene nannofossils occur in samples more rarely. Reticulofenestra pseudoumbilica (Gartner) is well preserved and abundant (Figure 7e). Discoaster cf. hamatus (Martini and Bramlette), D. cf. exilis (Martini and Bramlette), D. variabilis (Martini and Bramlette, D. aulacos (Gartner), D. molengraaffi (Tan Sin Hok), D. asymmetricus (Gartner), D. tamalis (Kamptner), D. cf. brouweri (Tan Sin
Hok), Catinaster caliculus (Bramlette and Martini), Cyclolithus $\mathrm{cf}$. inflexus (Kamptner), and Coronocyclus cf. nitescens (Kamptner) are rare.

Subsequent studies, using the electron microscope, detected Emiliana huxleyi (Lehman) from Martini's (1971) E. huxleyi NN 21 Zone. The nannofossil oozes are thus attributed to the Riss-Würm interglacial of Karangasian age.

On the western continental slope (Station 2306) a similar assemblage occurs differing from the Sinopian group in having fewer, poorly preserved coccoliths with abundant $E$. huxleyi. Some samples of highly calcareous brecciated mud (Station 2275) contain abundant foraminifers such as: Globorotalia inflata (Orb.), Globigerina bulloides (Orb.), G. triloculinoides (Plumm.), G. frontosa (Subb.), Globorotalia aff. Lensiformis (Subb.), Nodosaria spinescens (Rouss.), $\mathrm{n}$. sp., Eponides subumbonatus (Mjatlink), Cibicides midwayensis (Plumm.), C. perlucides (Nutt.), Uvigerina aff. costellata (Morozova), U. pygmea (Orb.), $U$. sp., Bolivina sp., Hastigerina micra (Cole), $H$. voluta (White), Bathysiphon nodosariaformis (Subb.), Nodosaria silesica (Jedlitscka), 

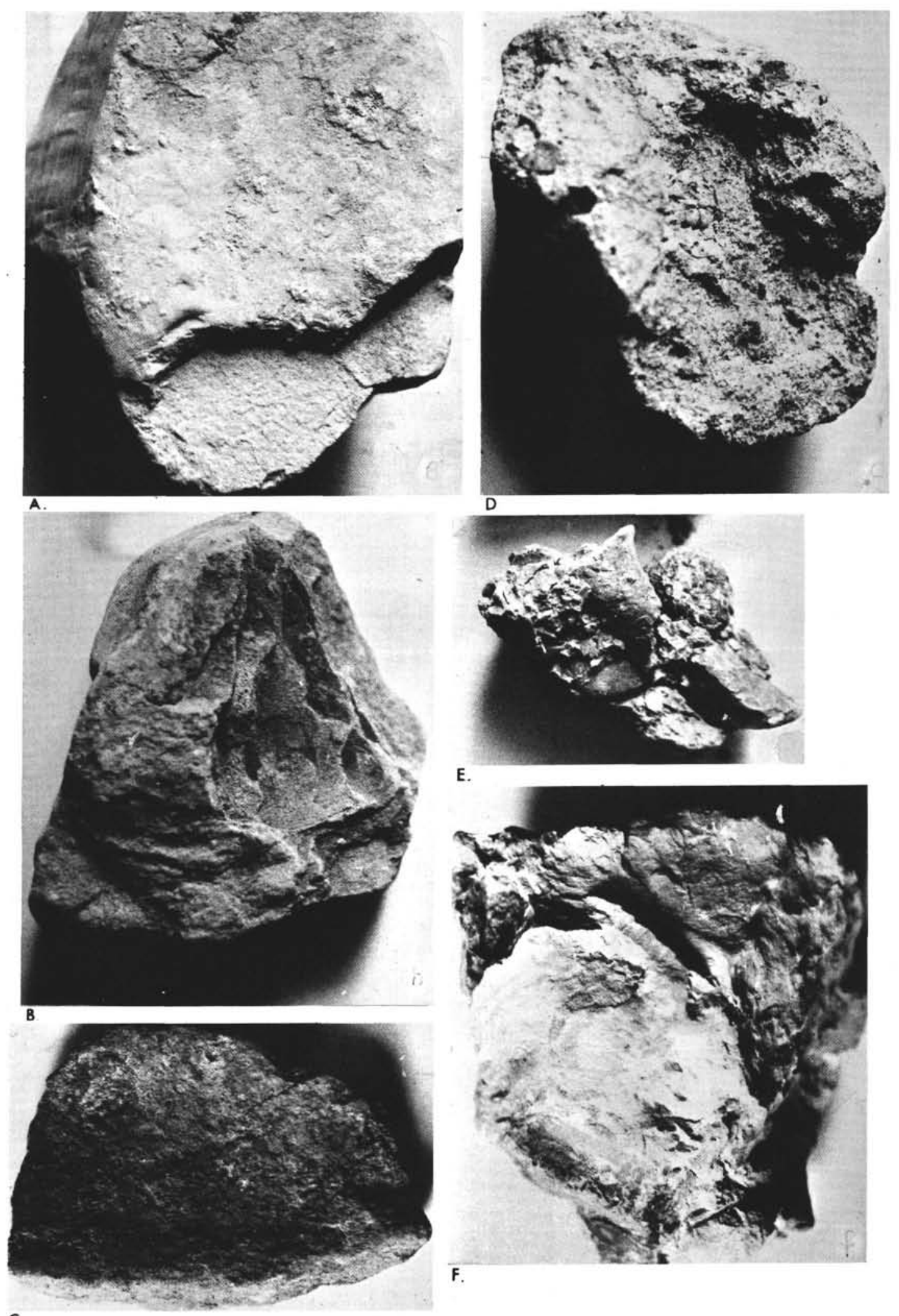

E.
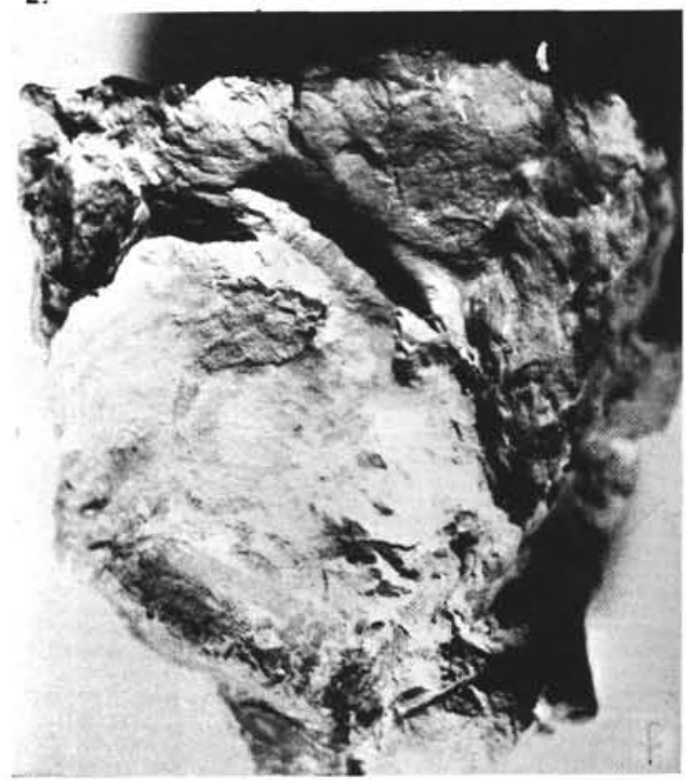

F.

c.

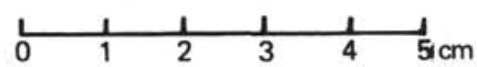

Figure 5. Photographs of rock samples taken by dredging. (A) Riss-Würm semiconsolidated finemicrolaminated nanno-oozes (Station 2275); (B) (C) polymictic sandstone (Station 2283); (D) andesite tuff (Station 2261); (E) pebbled conglomerate clay-cemented (Station 2008); (F) gray limestone (Station 2290). 
Lenticulina sp., Gyroidinoides octocametratus (Cushman and Hanna), Anomalina affinis (Hantken), A. acuta (Plumm.), Globigerina eocaena (Gumbel), Globorotalia velascoensis (Cushman), Acarinina pentacamerata (Subb.), Nuttalides trympyi (Nutt.), Acarinina crassaformis (Gall and Wiss.), and $A$. rotundinmarginata (Subb.). These muds also contain, in addition to Globorotalia inflata, a considerable admixture of Eocene forms such as: Globorotalia velascoensis (Cushman), Globigerina eocaena (Gumbel), and Acarinina rotundinmarginata (Subb.), etc.

On the seismic profiles crossing the slope opposite to the Sinop, a lower non-laminated unit (Ross et al., 1974, and Figure $3 \mathrm{~b}$ ). The lower unit comprises Cretaceous volcaniclastic and carbonate deposits. The upper unit consists of deeply eroded Cenozoic sediments and Pliocene-Pleistocene muds.

\section{THE SAKARYA SUBMARINE VALLEY}

From the lower western slopes of the valley at depths of 550 to 1270 meters (Figures 1D, 4C), dredging produced andesite prophyrites, augite, andesites (Figure 6b), tuffs and altered effusives, and indeterminant siliceous rocks which are dark greenish gray, banded to finely laminated and rarely porous. In addition, light gray biogenic limestones and mottled, micrograined, massive compact limestones were recovered. On the basis of their lithologic similarity to samples from Arkhangelsky's Ridge and the Sinopian area, they are believed to be Cretaceous in age.

On the east side of the valley, on the steep scarp of a terrace-shaped area (Station 2303, 1620-1675 m) outcrops of greenish and dark gray calcareous clays with silt interbeds occur. Fine laminations and finely dispersed iron sulfides are present in them. Palynological studies by A. V. Komarov indicate them to be middle to lower Pleistocene in age. Persistent rhythmic lamination in the unit is recorded on the seismic profile recorded by V. N. Moskalenko on R/V Academician S. Vavilov.

\section{THE CRIMEAN SLOPE}

\section{Southwest Area}

West of Cape Khersoness, on the lowermost steep slope (Station 2309, 1460-1760 m) Figures 1E, 4C) light gray, weathered granite porphyrites outcrop (see Figure $6 \mathrm{a}[\mathrm{C}, \mathrm{D}]$ ). These granites may correlate with those in the mid-Jurassic volcanic zone along the margin of the Kachinic Uplift (Muratov, 1973). At Station 2309, dark gray compact argillites, equivalent to the Taurian Formation $\left(T_{3}+J_{1}\right)$ occur. Jurassic and Cretaceous chalky limestones of white, gray, and greenish gray hue, and greenish gray, chalky and sandy marls crop out in the middle and lower parts of the Crimean continental slope (Figure 4D) (Stations 2283, 2289, 2290, and $2315 ; 800-1850 \mathrm{~m}$ ). The marls from Station 2315 contain exclusively Upper Cretaceous nannofossils such as : Watznaueria barnesae (Black), Cretarhabdus surirellus (Deflandre and Fert), Arkhangelskiella cymbiformis (Veschina), Prediscosphaera cretacea (Arkhangelsky), Cyclolithus subtilis (Shumenko (Figure 7e). This assemblage is analogous to the ones studied in the Ukraine and Crimean Upper Cretaceous deposits (Shumenko, 1971).

At Station 2283 (1000-1100 m) tuffaceous, polymictic sandstones with glauconite, glauconitic aleurolites and very sandy marls (Figures 5B, C; 6c [A]) occur. Similar sediments near Balaklava are Albian in age. The seismic profile passing near to Stations 2283 and 2290 (Figure 3D) shows that the southwestern shelf of Crimea is covered along its margin by layered, horizontal strata. Slump blocks, probably of Cretaceous age, occur on the slope. The foot of the slope probably is constituted of older rocks ( $\left.T_{3}-\mathrm{I}, \mathrm{J}_{2}-\mathrm{J}_{3}\right)$.

\section{Southeast Area}

At Station 2312 (240-290 m) on the upper slope, and at Stations 2310, 2311, 2313, $2314(480-845 \mathrm{~m})$ (Figures 1E, $4 \mathrm{E})$ outcrops of the Taurian Formation, widespread in Crimea and comprising quartz-felspathic sandstones, aleurolites, and argillites cover broad areas. At Stations 2310 and 2311, light gray Mesozoic(?) limestone fragments were recovered, as well as mid-Jurassic quartz porphyry effusives and Upper Jurassic and Cretaceous grits (Station 2311) (Figure $6 c[D]$ ) and tuffaceous sandstones (Station 2314). The limestones are micrograined, recrystallized, and compact or semicompact and chalky. The former resemble Jurassic limestones whereas the latter resemble Cretaceous limestones of the Crimea. Occurring in the grits are angular to sub-rounded fragments of argillite, feldspar, and quartz aleurolites and porphyries, presumably erosional products of the Taurian Formation. At Station 2313 cross-laminated quartz-felspathic sandstones, with carbonitized vegetable material, occur.

Thus, within the Crimean continental slope, the Taurian Formation and other mid-Jurassic sediments constitute the subsided core of the Crimean anticlinorium. Its southwestern part is covered by sediments of Late Jurassic and Early and Late Cretaceous age. The submerged Tuak anticlinorium is situated on the southeast part of the Crimean slope whereas the Sudak synclinorium, characterized by Jurassic deposits, is located along the foot of the slope; its most deeply subsided portion, the Majkop trough, is within the abyssal plain.

\section{CONCLUSIONS}

1. Dredging in the Black Sea has revealed that: (a) Paleogene clayey-sandy flysch occur on the Caucasian slope near Gelendgik-Novorossisk; (b) an Early and Late Cretaceous volcanogenic and sedimentary series on Arkhangelsky's Ridge and the Sinopian slope; (c) Cretaceous(?) effusives occur in the Sakarya submarine valley, as well as lower and middle Pleistocene clays on the slopes of the valley; (d) the Taurian Formation, Cretaceous granite porphyrites and mid-Jurassic(?) quartz porphyry occur on the Crimean slope; and (e) Karangathic nannofossil oozés and sapropelic muds are present on the Sinopian slope.

2. (a) The Paleogene flysch trough and the northern side of the Majkop trough extend into the Caucasian slope near Gelendgik-Novorossisk. (b) The eastern Pont structures and the Cretaceous andesite zone extend into the Anatolian slope. (c) The Crimean anticlinorium, partially buried by middle to late Mesozoic sediments, extends into the Crimean shelf and slope.

3. Composition of the Cretaceous sandstones neàr Crimea indicate the source was from emergent areas composed of Paleozoic, Triassic, and Jurassic rocks in the area where the present Black Sea deep water basin exists (Yurk and Dobrovolskaya, 1965; Chernov, 1970; Brinkmann, 1974). 


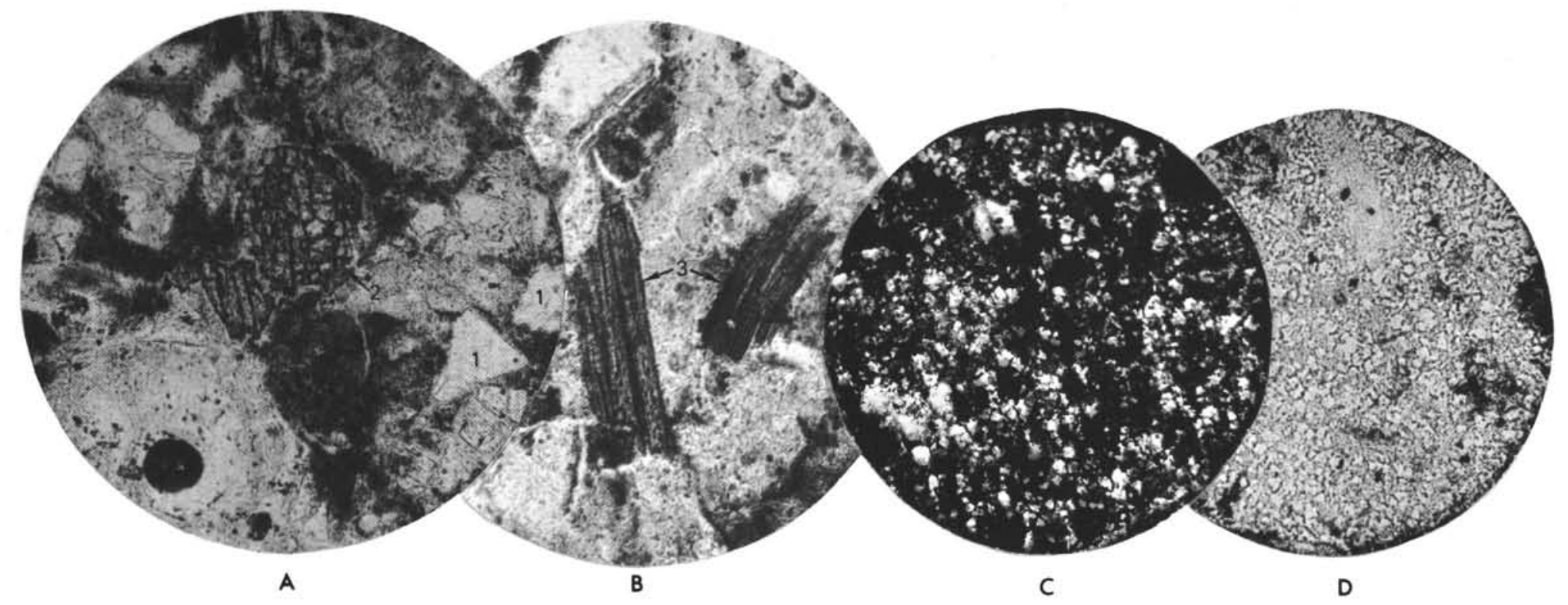

Figure 6a. Microphotographs of rock thin sections. (A), (B) andesite tuff (Station 2261) 50; (C), (D) granite-porphyry (Station 2309) $(+$ nicols, II $) \times 40$. 1-plagioclase, 2-pyroxene, 3-biotite.

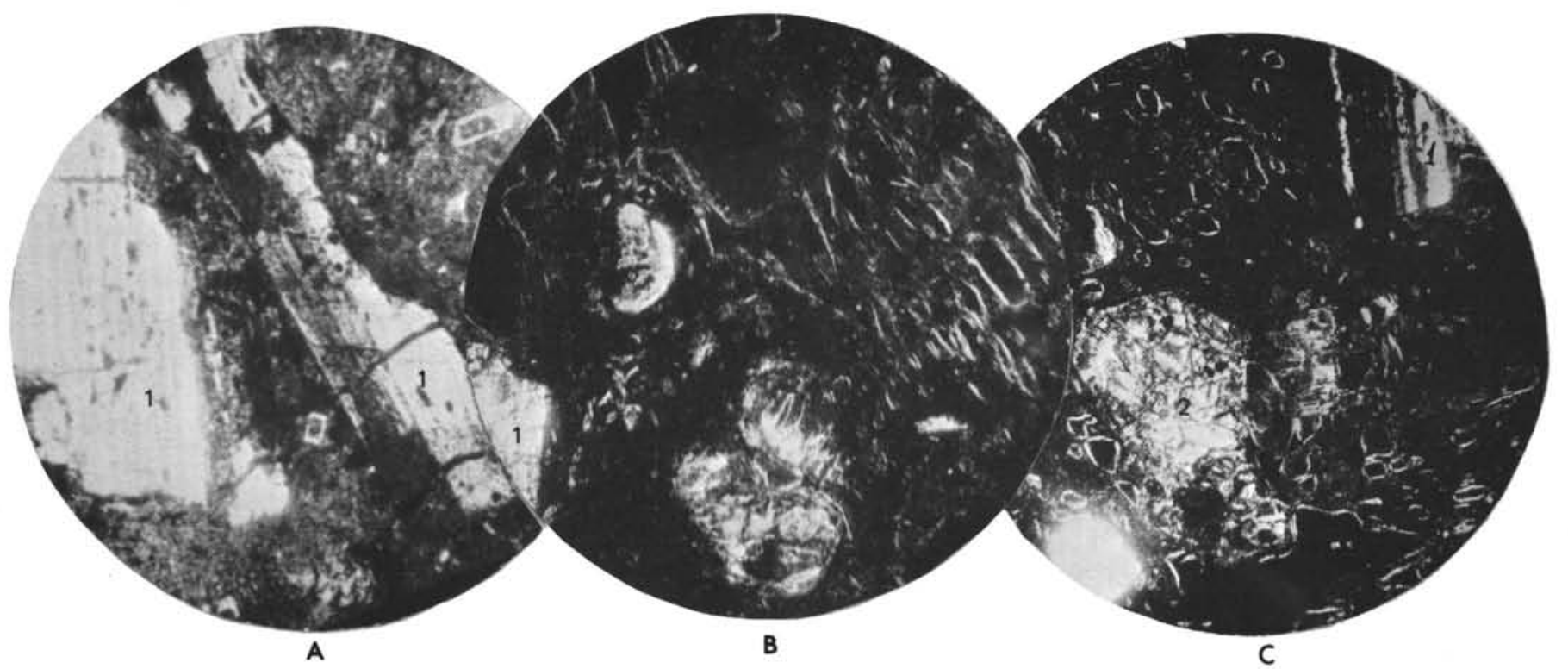

Figure 6b. (A) andesite-porphyrite (Station 2277) 40; (B), (C) augite andesite (Station 2278) (+ nicols) 55. 1-plagioclase, 2-augite. 


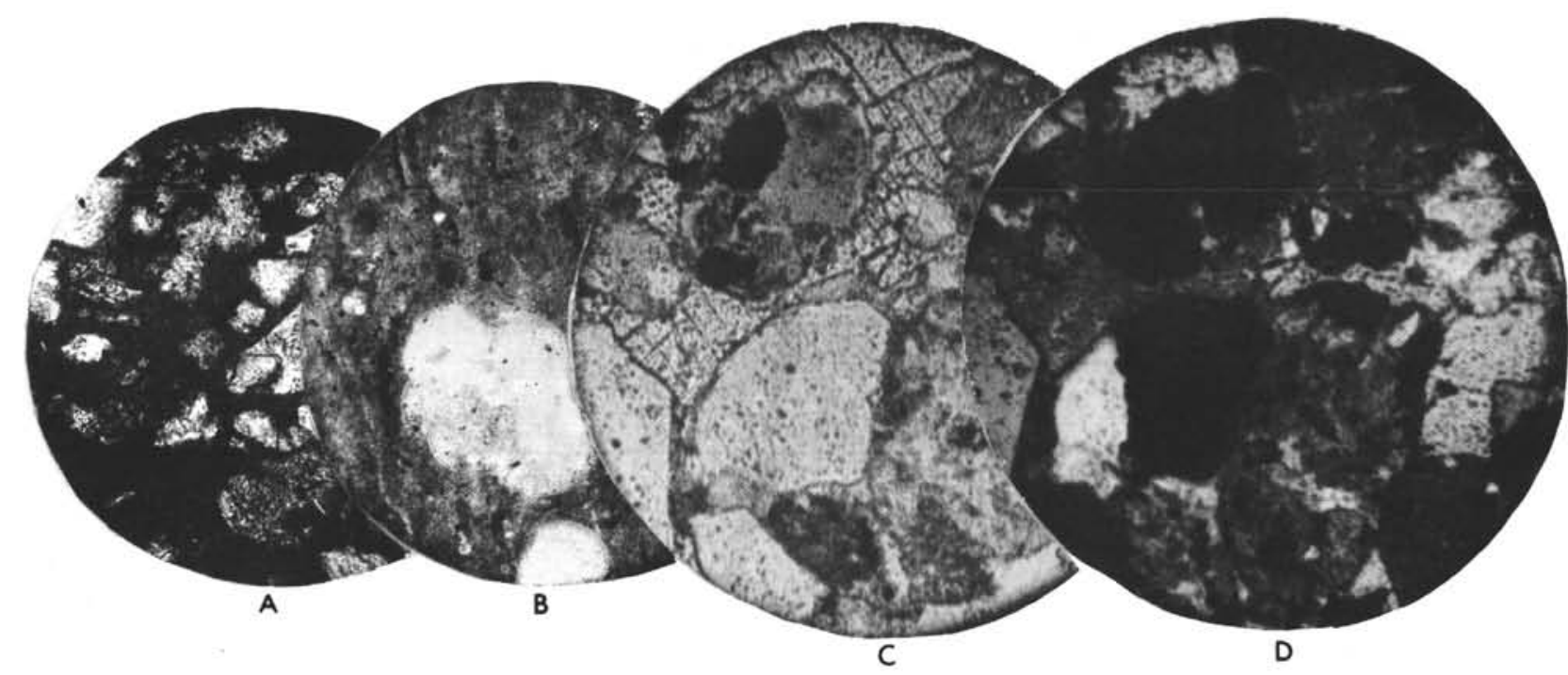

Figure 6c. (A) polymictic sandstone (Station 2283) (+ nicols) 40; (B) nannofossil ooze enriched in organic matter and foraminifers (Riss-Würm age)(Station 2275)(micols II) 40; (C), (D) gritstone (Station 2311) $(+$ micols, II) $\times 50$. 

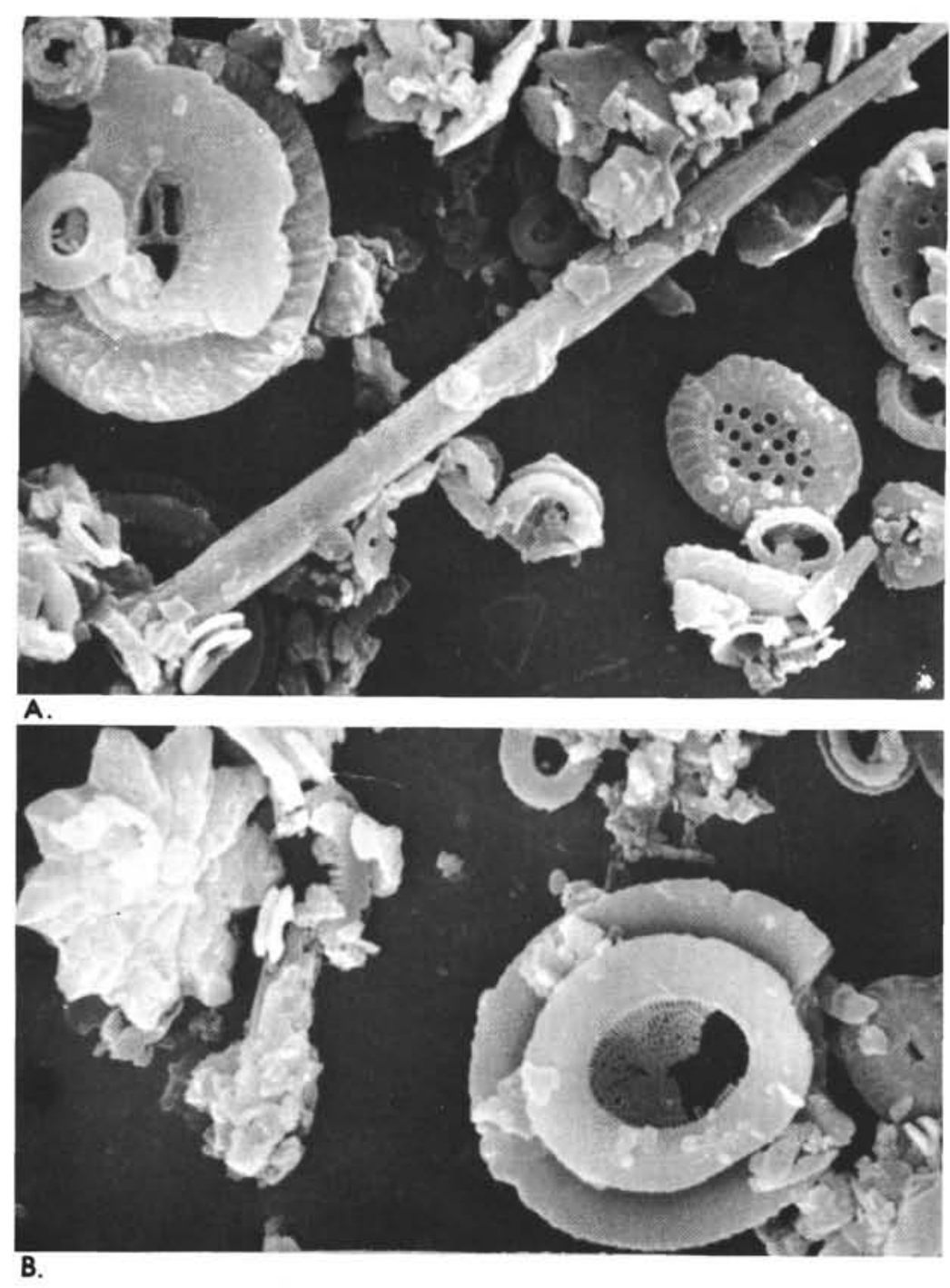

Figure 7a. Microphotographs of nannofossils. (A) Coccolithus tenuiforatus (Clocchiatti and Jerkovich), Blackites sp., Prinsius fenestratus (Deflandre), Discolithus multiporus (Kamptner), and undetermined coccolithus $\times 8000$ (Station 2275, Sample B-94). (B) Discoaster barbadiensis (Tan Sin Hok), Reticulofenestra placomorpha (Kamptner), Coccolithus eopelagicus (Bramlette and Riedel $\times$ 500, (Station 2275, Sample B-94).
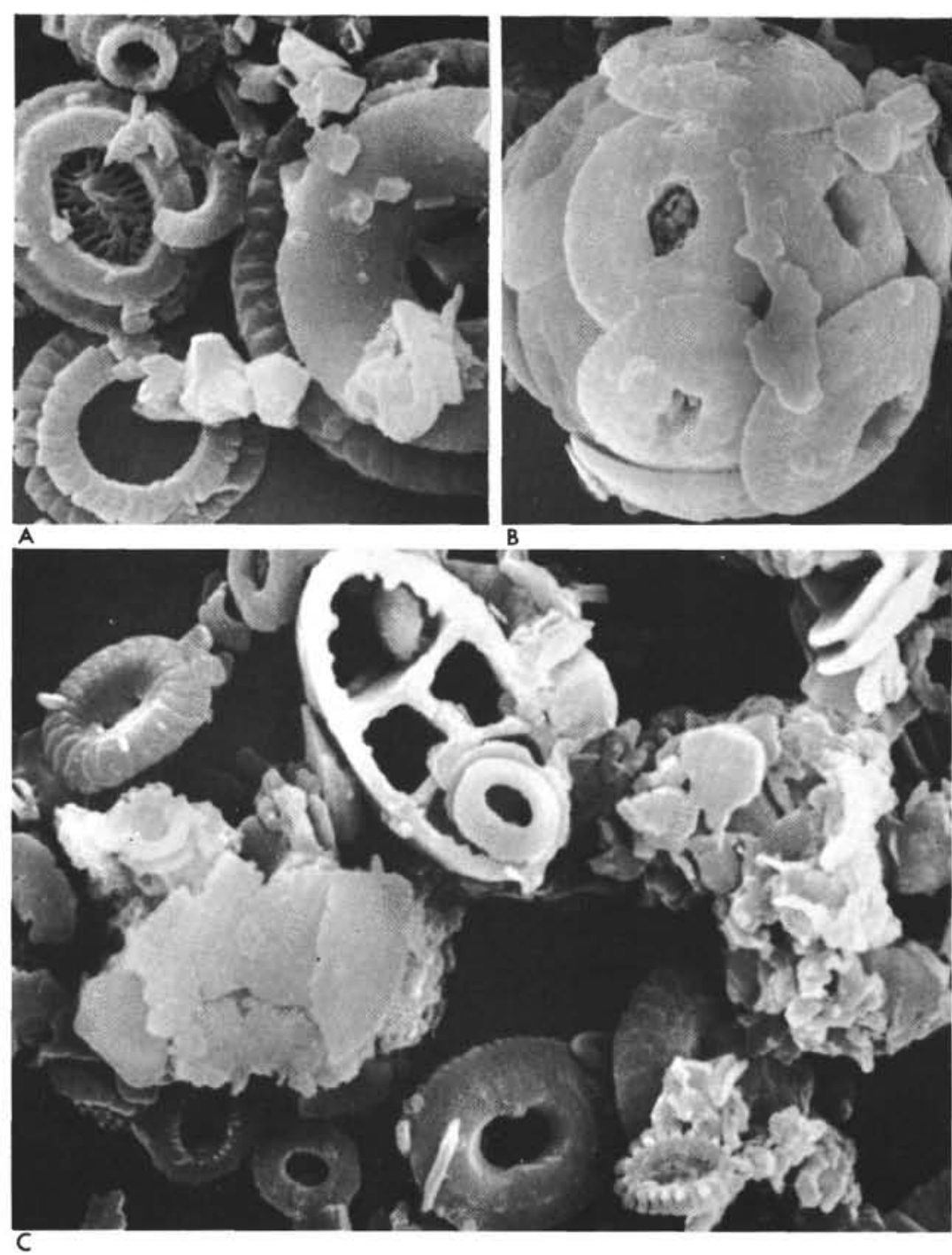

Figure 7b. (A) Cribrocentrum martinii (Hay and Towe), Cyclolithus cf. annulus (Cohen), Coccolithus formosus (Kamptner) X 6000 (Station 2275, Sample B-94); (B) Coccolithus cf. tritus (Roth), Zygolithus dubius (Deflandre), Toweius sp., Emiliania huxley (Lehmann) X 6200 (Station 2275, Sample B-94). 

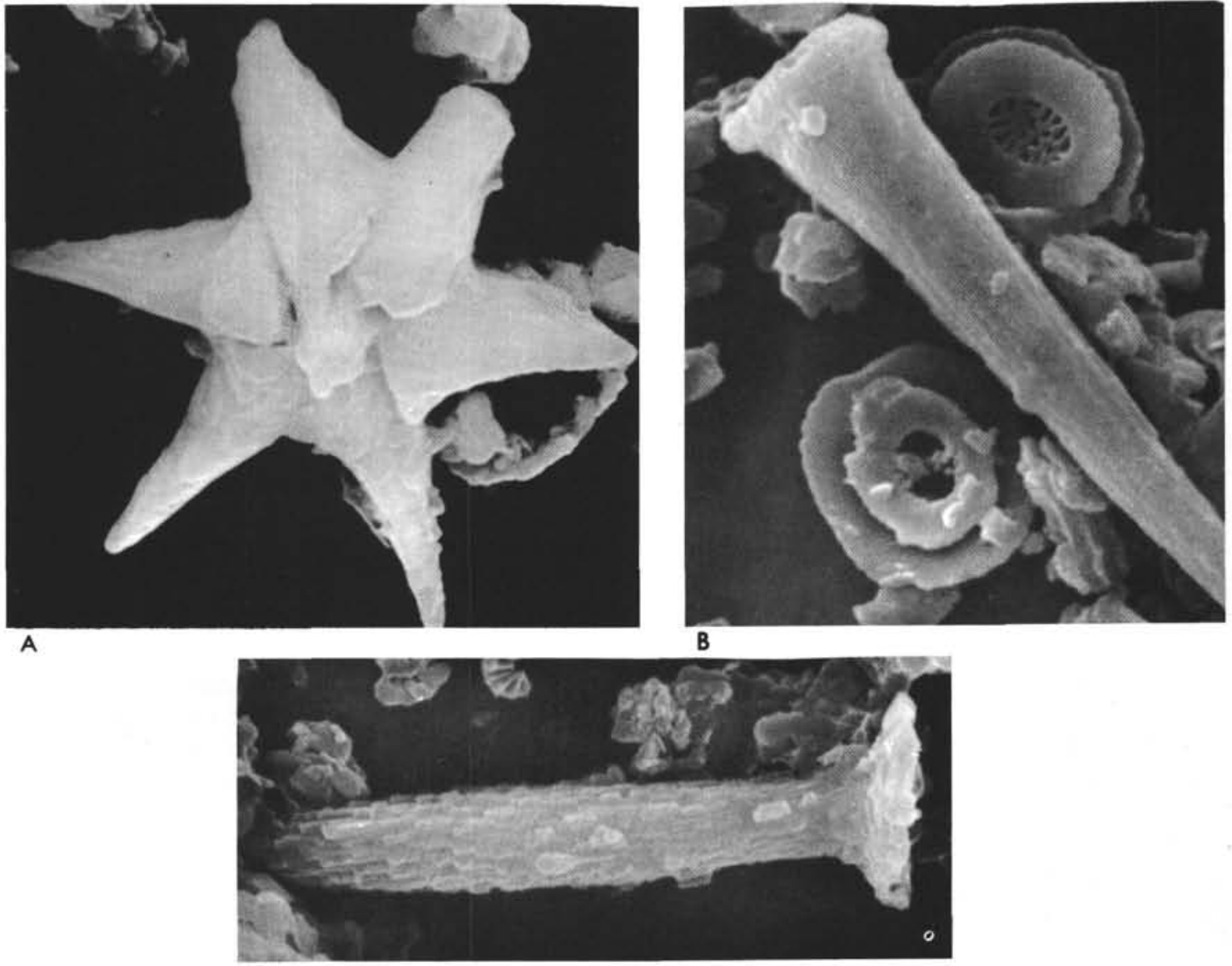

C
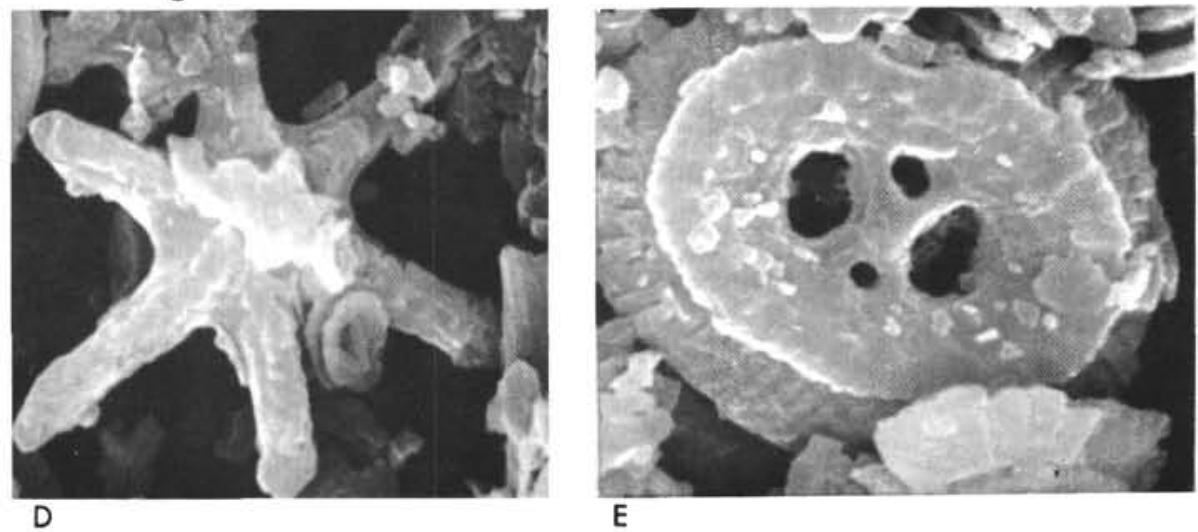

Figure 7c. (A) Discoaster lodoensis (Bramlette and Sullivan) $\times 5000$ (Station 2299, Sample 4); (B) Rhabdolithus solus (Perch-Nielsen) X 3600 (Station 2299, Sample 4); (C) Blackites spinulus (Levin), Reticulofenestra pseudoumbilica (Gartner) X 6500 (Station 2275, Sample B-94); (D) Discoaster tani modifier (Bramlette and Riedel) X 4000 (Station 2275, Sample B-94); (E) Chiasmolithus oamaruensis (Deflandre) X 5500 (Station 2275, Sample B-94). 

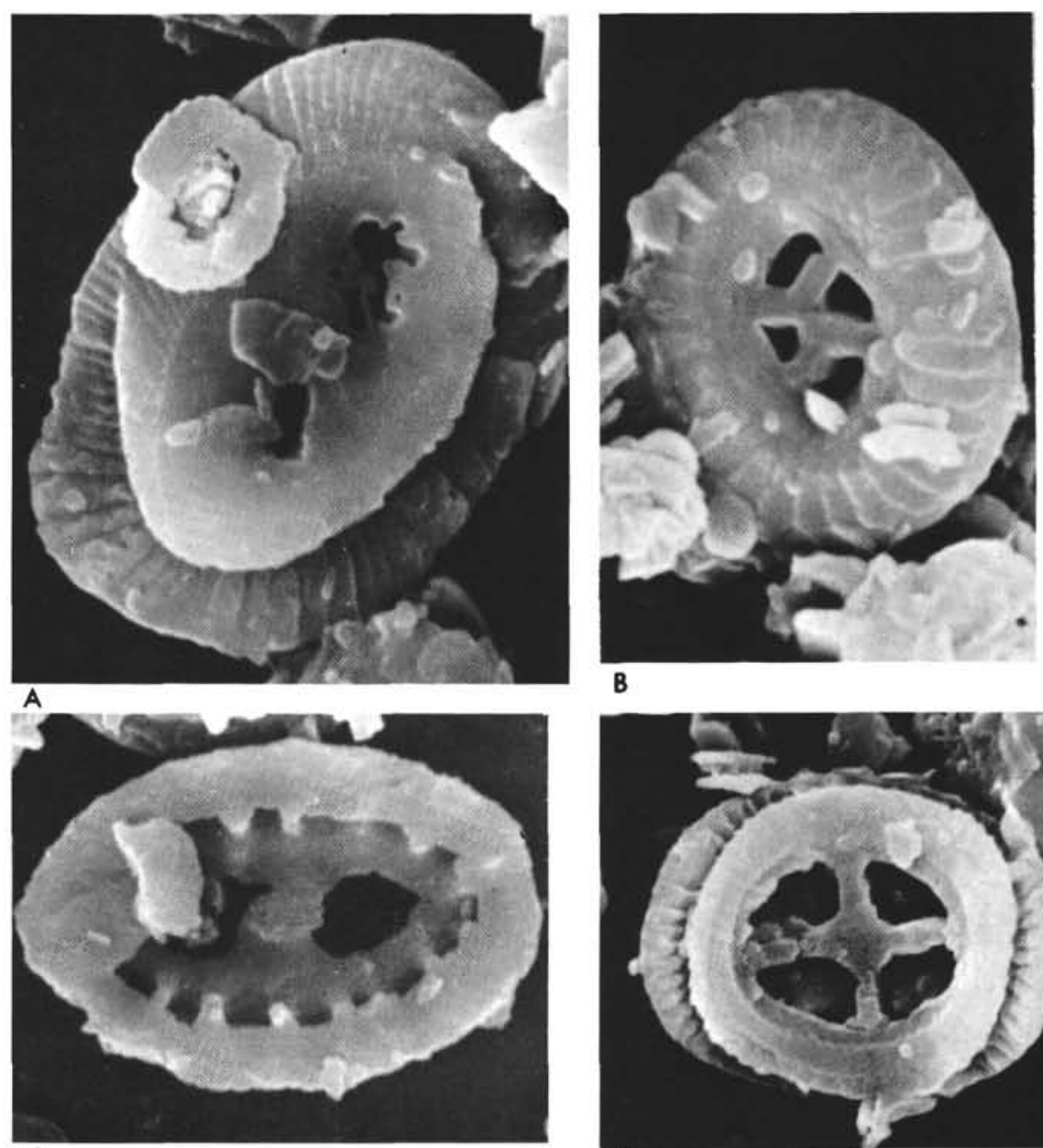

B
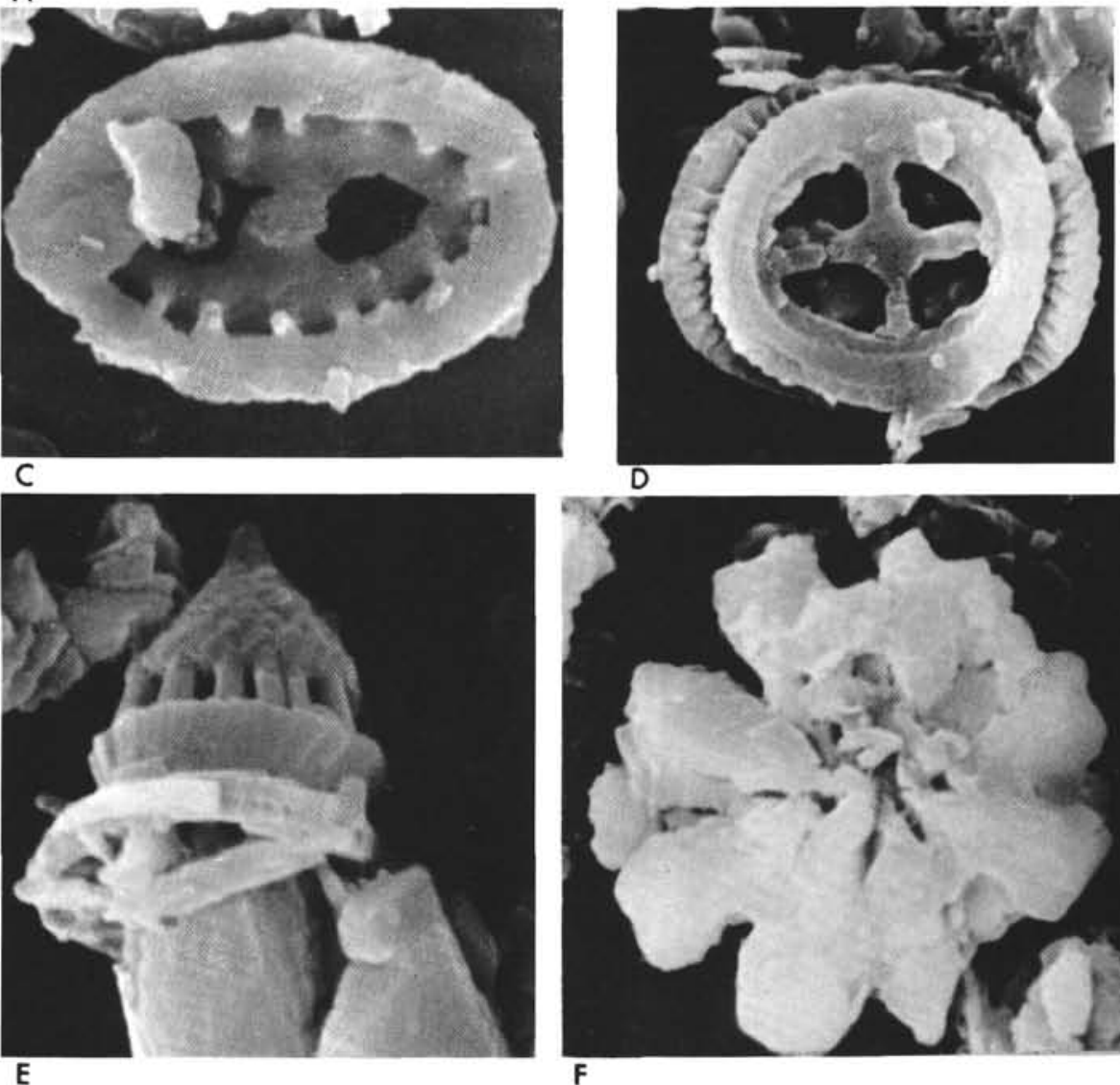

D

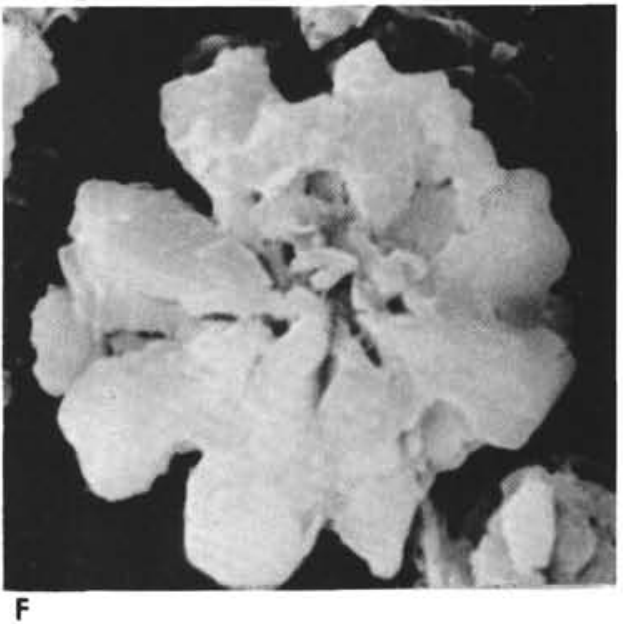

Figure 7d. (A) Helicopontosphaera lophota (Bramlette and Sullivan) $\times 6500$ (Station 2275, Sample B-94); (B) Chiasmolithus titus (Gartner) X 6500 (Station 2275, Sample B-94); (C) Transversopontis prava (Locker) X 6500 (Station 2275, Sample B-94); (D) Cruciplacolithus delus (Bramlette and Sullivan) X 4500 (Station 2299, Sample 4);(E) Naninfula deflandrei (Perch-Nielsen) $\times 7500$ (Station 2275, Sample B-94); (F) Discoaster molengraaffi (Tan Sin Hok) X 4000 (Station 2299, Sample 4). 


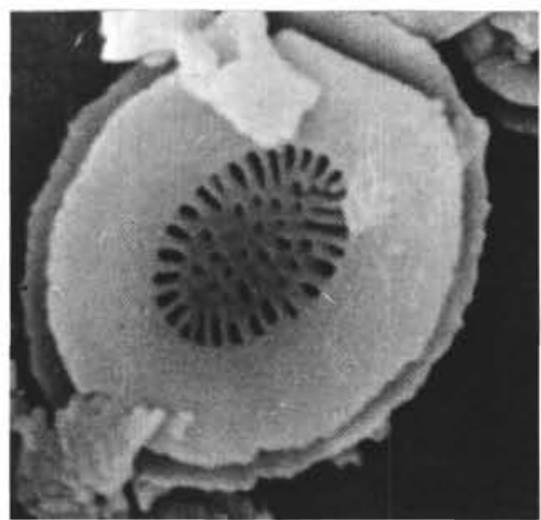

A

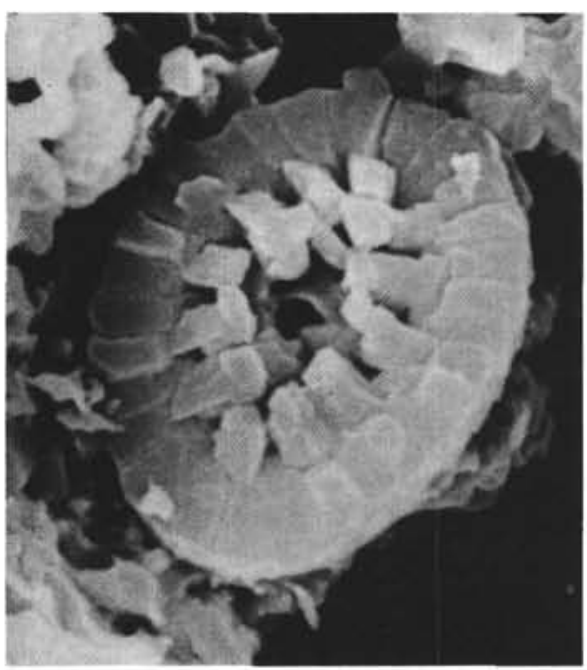

C

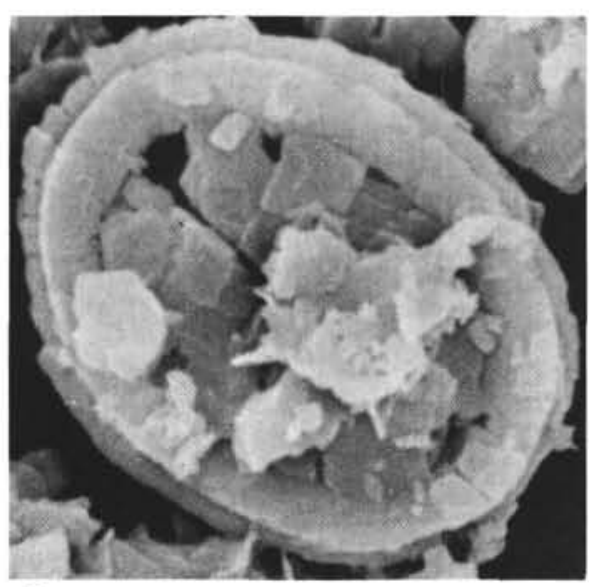

E

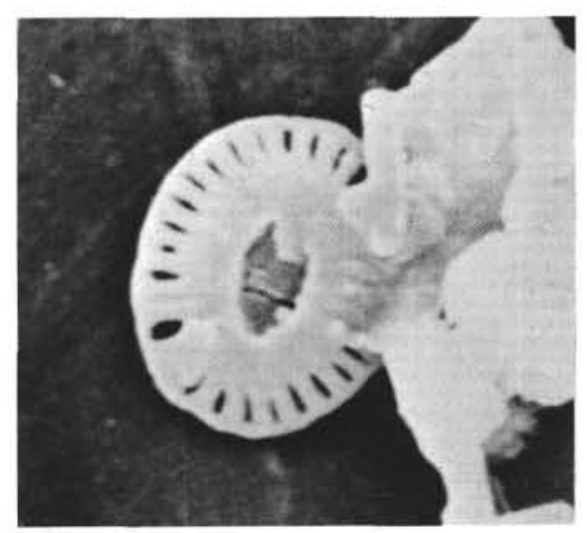

B

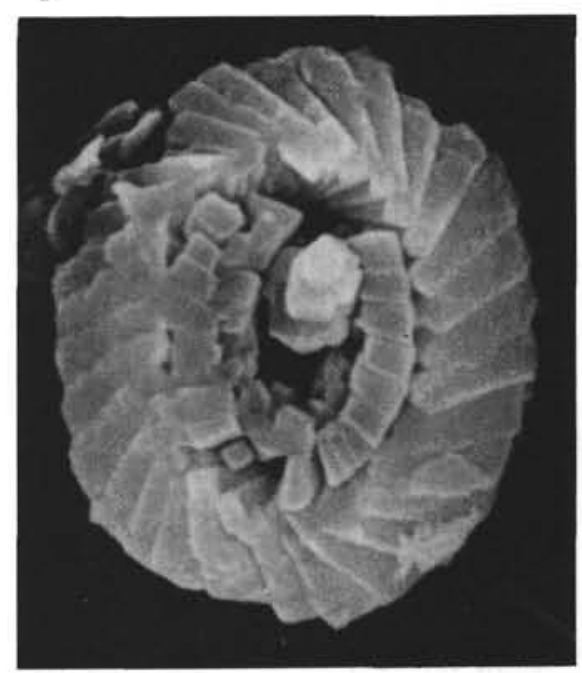

D

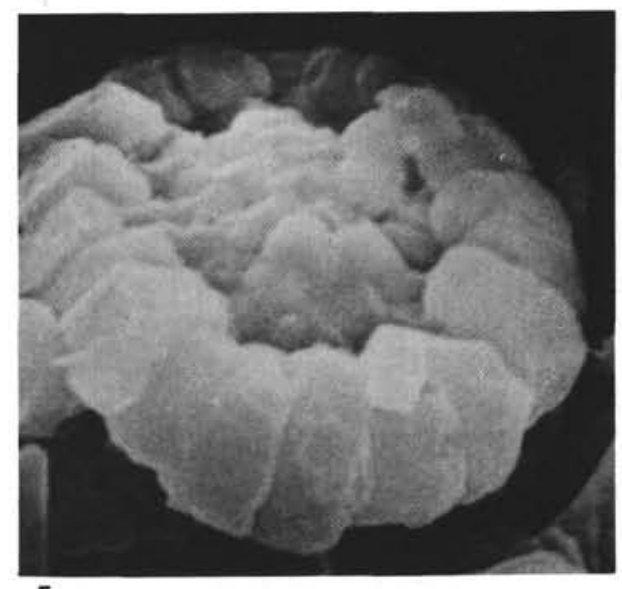

$\mathbf{F}$

Figure 7e. (A) Reticulofenestra pseudoumbilica (Gartner) $\times 8000$ (Station 2275, Sample B-94); (B) Emiliania huxleyi (Lohmann) $\times 10,000$ (Station 2299, Sample 4); (C) Cretarhabdus surirellus (deflandre and Fert) $\times 6000$ (Station 2315, Sample 3); $\gamma(D)$ Watznaueria barnesae (Black) $\times 7000$ (Station 2315, Sample 3); (E) Arkhangelskiella cymbiformis (Vekshina) X 6000 (Station 2315, Sample 3); (F) Cribrôsphaerella ehrenbergi (Arkhangelsky) $\times 8700$ (Station 2295, Sample B-130). 
4. Upper Cretaceous limestones on the Crimean continental slope confirm Muratov's (1955) belief that, in Late Cretaceous time, the Black Sea was epicontinental.

5. Pliocene-Quaternary movements, along a series of longitudinal fractures, exposed the Mesozoic-Cenozoic rocks within the basin which are thinly covered by late Cenozoic sediments. Seismic evidence does not indicate that folded coastal structures extend into the central basin area where thick, horizontally bedded deposits, of which the lower part is Jurassic and Cretaceous in age (Neprochnov et al, 1974), are widespread.

\section{ACKNOWLEDGMENTS}

The authors are grateful to our colleagues A. V. Komarov, S. V. Chaboishvili, and A. S. Zhigunov for helping in marine studies; to N. G. Prokoptsev for petrology consultations; to V. L. Egoyan, G. A. Malakhova, and D. Strotcheva from the Laboratory of Stratigraphy of Krasnodar-NIIneft for their microfaunal determinations; to E. M. Emelyanov from the Atlantic Branch of the P. P. Shirshov Institute of Oceanology for his assistance in translation of this article; and to D. A. Ross, Y. P. Neprochnov, the co-chiefs of Glomar Challenger Leg 42B and other participants of the leg for giving us the opportunity to publish this article in the Initial Reports. Also we thank to D. A. Ross and J. L. Usher for editorship of our contribution.

\section{REFERENCES}

Brinkmann, R. 1974. Geologic relations between Black Sea and Anatolia. In Degens, E. T. and Ross, D. A. (Eds.), The Black Sea-geology, chemistry and biology: Am. Assoc. Petrol. Geol. Mem. 20, p. 63-76.

Chernov, V. G., 1970. K. voprosu o stroenii dna Chernogo morya $\mathrm{k}$ yugu ot Kryma. (On the problem of the Black Sea bottom structure southwards from the Crimea): Geotektonika, p. 8289.

Djakonov, A. I., Tsagareli, A. L., Malovitsky, Ya. P., Baidov, F. K., and Terekhov, A. A., 1972. Tektonicheskaya karta zapadnoj chasti Kavkaza in prilegayushchej chasti akvatorii Chernogo morya. (Objyasnitelnaya zapiska). (Tectonic map of the Wester Caucasus and adjacent part of the Black Sea water area): Pechatno-mnozhitelnaya gruppa BIM, M., p. 115.

Erentoz, K., 1967. Kratkii obzor geologii Anatolii (Malaya Aziya). (Brief survey of Anatolia geology. Asian Minor): Geotektonika, p. 31-46.

Malovitsky, Ya. P. and Terekhov, A. A., 1972. Novye svedeniya o strukture mezo-kainozoiskikh obrazovanii v Prikavkazskoi chasti Chernogo morya (po materialam seismicheskikh issledovanii MOV). (New data on the structure of MesoCenozoic deposits in the Black Sea Pre-Caucasian area): Morskaya geologiya i geofizika, vyp. III, Riga, p. 94-112.
1973. O prirode podvodnogo khrebta Arkhangelskogo v Chernom more. (On the nature of submarine Arkhangelsky's Ridge in the Black Sea): Dokl. AN SSSR, geol., v. 208.

Martini, E., 1971. Standard Tertiary and Quaternary calcareous nannoplankton zonation: Second Plankt. Conf. Proc., Roma.

Muratov, M. V., 1955. Istoriya tektonicheskogo razvitiya glubokoi vpadiny Chernogo morya i ee vozmozhnoe proiskhozhdenie. (History of tectonic development of the Black Sea deep basin and its possible origin): Byull. M.O-va Isp. prirody. Otd. geologii, v. XXX, p. 27-49.

1960. Kratkii ocherk geologicheskogo stroeniya Krymskogo poluostrova. (A brief survey of geological structure of the Crimean peninsula): Gosgeoltekhizdat, M., p. 207. 1973. Geologiya Krymskogo poluostrova. (Geology of the Crimean peninsula). V kn. "Rukovodstvo uchebnoi geologicheskoi praktike v Krymu”, v. II, Izd. "Nedra", M., p. 192.

Neprochnov, Yu. P., Neprochnova, A. F., and Mirlin, Ye. G., 1974. deep structure of Black Sea basin. In Degens, E. T. and Ross, D. A. (Eds.), The Black Sea-geology, chemistry, and biology: Am. Assoc. Petrol. Geol., Mem. 20, p. 35-49.

Ross, D. A., Uchupi, E., and Bowin, C. O., 1974. Shallow structure of Black Sea basin. In Degens, E. T. and Ross, D. A. (Eds.), The Black Sea-geology, chemistry and biology:Am. Assoc. Petrol. Geol. Mem. 20, p. 11-34.

Terekhov, A. A., Khakhalev, E. M., and Malovitsky, Ya. P., 1970. Novye dannye o geologicheskom stroenii prikavkazskogo kontinentalnogo sklona Chernogo morya. (New data on geological structure of Black Sea Pre-Caucasian continental slope): Dokl. AN SSSR, v. 195, p. 174-177.

Terekhov, A. A., Mamoshina, K. N., and Moskalenko, E.P., 1973. O prodolzhenii struktur Severo-Zapadnogo Kavkaza vo vpadinu Chernogo morya. (About prolongation of the Northwestern Caucasus structures into Black Sea basin): Geotektonika, p. 113-120.

Shardanov, A. N., 1960. Tektonicheskoe stroenie severozapadnogo Kavkaza. (Tectonic structure of the northwestern Caucasus): Tr. KF VNIIneft, p. 82-119.

Shimkus, K. M. and Shumenko, S. I., 1975. O nakhodkakh nanoplanktonnykh i glinisto-sapropelevykh osadkov pozdnego pliotsena-rannego pleistotsena nayuzhnom sklone Chernogo morya. (On occurrences of nanno-plankton and clay-sapropelic sediments of late Pliocene-early Pleistocene on the southern Black Sea slope): Okeanologiya, v. 15, p. 1087-1089.

Shumenko, S. I., 1971. Litologiya i porodoobrazuyushchie organizmy (kokkolitoforidy) verkhnemelovykh otlozhenii vostochnoi Urkrainy i oblasti Kurskoi magnitnoi anomalii. (Lithology and rock-forming organisms (coccolithophorides) of Upper Cretaceous deposits of Eastern Ukrain and Kursk magnetic anomaly areas): Izd. Kharkovskogo Un-ta, p. 160.

Yurk, Yu. Yu. and Dobrovolskaya, T. I., 1965. Pifeiskie i paleozoiskie valuny granitov Kryma. (Riphean and Paleozoic blocks of the Crimea granites): Mater. Karpato-Balkanskoi geol. assotsiatsii, VII kongress, ch. 3, Sofia. Izd. Bolg. AN. 